\title{
GLACIER ICE STRUCTURES INFLUENCE ON MORAINES DEVELOPEMENT (HØRBYE GLACIER, CENTRAL SPITSBERGEN)
}

\author{
IZABELA SZUMAN, LESZEK KASPRZAK \\ Adam Mickiewicz University, Institute of Geoecology and Geoinformation, Poznań, Poland \\ Manuscript received January 10, 2010 \\ Revised version March 2, 2010
}

Szuman I., KaSPRZAK L., 2010. Glacier ice structures influence on moraines developement (Hørbye glacier, Central Spitsbergen). Quaestiones Geographicae 29(1), Adam Mickiewicz University Press, Poznań 2010, pp. 65-73, Figs 4. ISBN 978-83-232-2136-4. ISSN 0137-477X. DOI: 10.2478/v10117-010-0007-4

\begin{abstract}
Geomorphological and basic sedimentological investigation of controlled moraine system was carried out at the ice surface and within the moraine complex zone of the Hørbye glacier (Central Spitsbergen). The Hørbye glacier creates controlled moraine chains regarding transversal fractures and longitudinal foliation. The forms parallel to the ice flow direction are represented by medial moraines, whereas transversal ones by thrustmoraines. Both arrangements are clearly visible. However, thrust and shear planes are more effective in creating forms, both on the ice surface and in the moraine complex. The longitudinal landforms are less distinct, moreover they are coarser-grained and worse rounded, in contrast to the material from shear and thrust plains which is finer and better rounded. The study area can be divided into three subzones: clean ice surface, debris covered ice fractures and moraine complex. The outer and inner sandur plain were not taken under consideration. It is suggested that present arrangement of both thrust or shear plains and longitudinal foliation controls formation of foreland relief. This hypothesis has a particular sense in understanding construction of modern sedimentary basins as well as the mechanism of terminoglacial relief formation with regend to ice structure.
\end{abstract}

KEYWORDS: Arctic , Spitsbergen, ice structure, controlled moraines, sedimentary basins

Izabela Szuman, Leszek Kasprzak, Adam Mickiewicz University, Institute of Geoecology and Geoinformation, Department of Geomorphology, Dzięgielowa 27, 61-680 Poznań, Poland, szuman@amu.edu.pl, l.kasp@amu.edu.pl

\section{Introduction}

Ice structure differs depending on ice flow character. Firstly, the longitudinal foliation is caused by lateral compression of ice which causes sub- and englacial material folding (Glasser et al., 1998) due to lateral reduction of space in the valley. Material released from this folded ice can be observed on the ice surface as a medial moraine set, that is subparallel to ice flow. Secondly, fractures transverse to the ice flow are connected mostly with trusting and shearing processes (Bennett et al., 1999; Glasser et al., 1998) and compressive ice flow. This compression is typical for the snout part and for the zone between warmer and colder part of a glacier - in case of polythermal valley glaciers (Lucas, 2005).

There are two main manners of debris incorporation into the ice mass, topward and downward. In the first one material derives from the substrateare incorporated by folding and thrusting mechanism (Woodward et al., 2002). 
Whereas, the downward debris delivery is based on covering debris from rock fall, aeolian activity and avalanches by new accreted snow and ice. Below the equilibrium line, in the ablation zone, where melting is more intense, the sediments are released from englacial position to the ice surface. The material melted out from thrust or shear planes forms thrust moraines, whereas melting out from longitudinal fractures forms medial moraines. Such a system of both longitudinal and transverse forms, connected with debris layout within the ice, was considered by Boulton $(1967,1972)$ and Evans (2009) as an element of controlled topography or controlled moraines. Those moraines are defined as material deposited supraglacially with clear linearity inherited from debris concentration in the ice (Benn \& Evans, 1998). The effectiveness of debris uplifting and production of sediment cover on ice surface depends on (1) concentration of material within foliation, debris bands, thrust and shear planes, (2) the angle of those planes (Bennett et al., 1999), (3) the speed of thrusting processes (4) thermal regime of glacier and (e.g. Sollid \& Sørbel, 1988; Lucas, 2005) (5) and melting out mechanism. The presence of debris-rich thrusts has been confirmed by e.g. Murray et al. (1997) and Hambrey et al. (1999).

The role of ice structure in landforms development has been slightly studied (Boulton, 1967, 1972; Bennett et al.; 1998, 1999; Hambrey et al. 1997, 1999; Glasser et al., 1998; Lucas, 2005; Graham et al., 2007; Lucas, 2007) and some papers only mention this problem (e.g. Lyså \& Lønne, 2001). Bennett et al. (1999) distinguished for the Kongsvegen glacier four main ice structures: stratification, crevasse traces, thrust and longitudinal foliation. The last two will be considered in this paper.

Climate warming caused a continuous recession of most Svalbard's glaciers since the end of the Little Ice Age (LIA) (e.g. Dowdeswell et al., 1997; Ziaja, 2001; Zagórski et al. 2008). This retreat gives a perfect occasion to study uncovered surface relief with reference to appearance of moraines on the ice surface.

This study provides description of arrangement of landforms controlled by ice fractures which generate patterned sedimentation in the marginal zone. The aim of the paper is to verify a hypothesis about moraine formation controlled by ice structure, as well as to determine a significance of landforms assemblage in the development of sedimentary basins.

\section{Study area}

The Hørbye glacier $\left(16^{\prime} 15^{\circ} \mathrm{E}, 78^{\prime} 46^{\circ} \mathrm{N}\right)$ is a valley glacier in central part of Spitsbergen (Svalbard, Fig. 1) localized on the northern ending of Petunia Bay. The glacier is about $6.75 \mathrm{~km}$ long and in totals c. $13.9 \mathrm{~km}^{2}$ (Rachlewicz et al., 2007). It is also considered as a polythermal type (Gibas et al., 2005) and was suggested as surge type glacier (Karczewski, 1989; Gibas et al., 2005). The glacier is situated in the neighborhood of the Billefjorden Fault Zone, one of the main features of Spitsbergen geology, where methamorphic and sedimentary rocks are present. Hørbye glacier owns asymmetrical shape, what is an effect of its position in relation to the mountains ridges. The longer, western part of the glacier is hidden during part of the day in the mountains shade and the eastern part, situated nearer the central part of a valley, has smaller extent.

The glacier has been a subject of few earlier researches (Karczewski 1989; Karczewski \& Rygielski 1989; Gibas et al. 2005; Rachlewicz, 2007). The Hørbye glacier, like most of the glaciers in this region, has been in continuous recession phase since the end of the LIA (e.g. Svendsen and Mangerud 1997), except the suggested surge episode (Karczewski 1989; Gibas et al. 2005). Hørbye glacier end moraines, that are about $1.5 \mathrm{~km}$ away from the present ice margin (Rachlewicz et al. 2007), mark the maximal extent of the glacier during the maximum of the LIA.

The study considers only the two defined arrangements: thrust- and longitudinal moraines. In this contribution forms perpendicular (but only those that do not represent ice margin stagnation) and parallel to the ice flow are considered. The transverse and longitudinal fractures overlap each other. Fractures arrangement is better visible in a lower part than in the upper part of the glacier. They are underlined by debris cover on the ice surface. Hence, the study area can be divided according to well-defined landforms on the ice surface and in front of it (Fig. 2): 


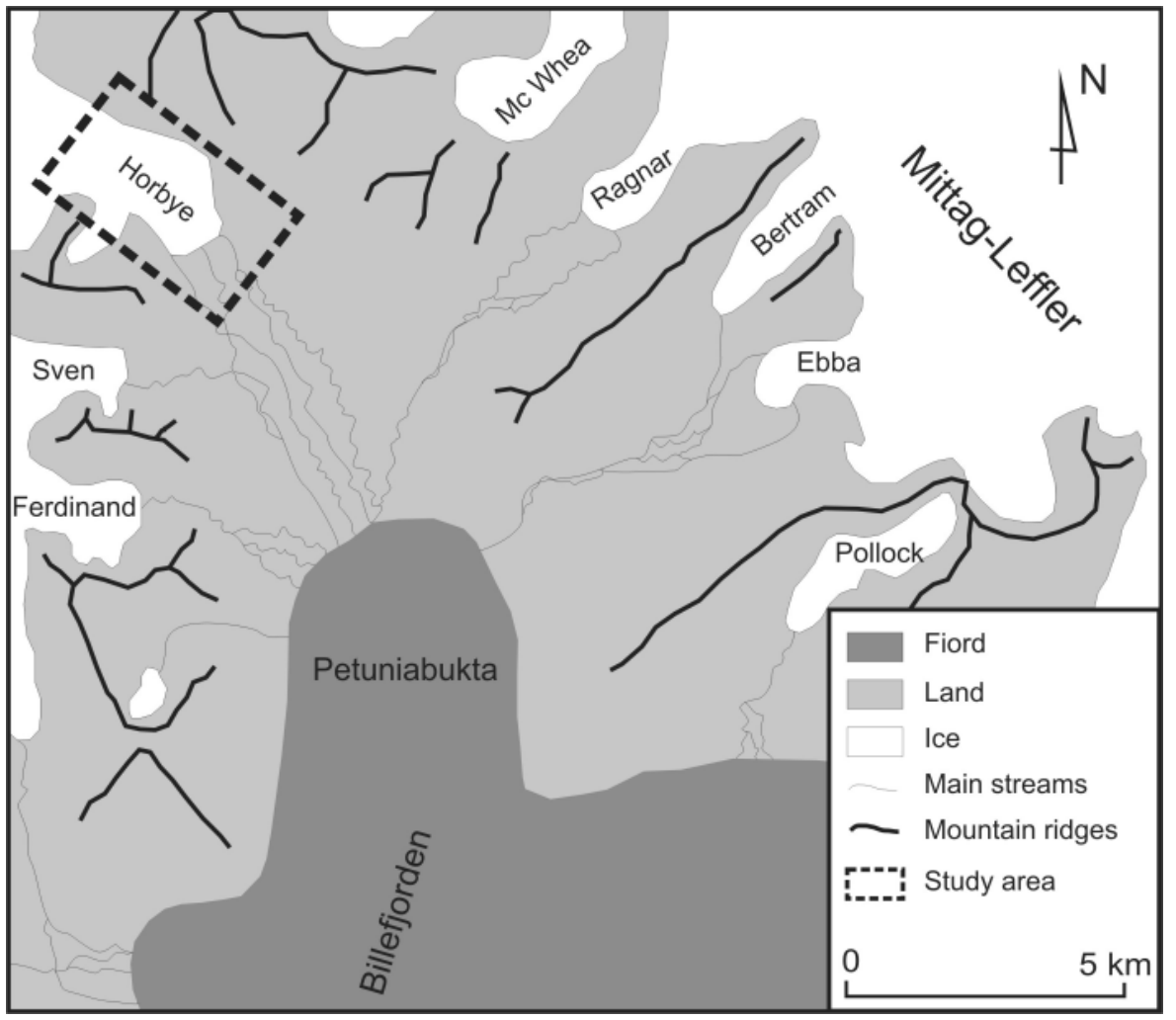

Fig. 1. Location of the study area

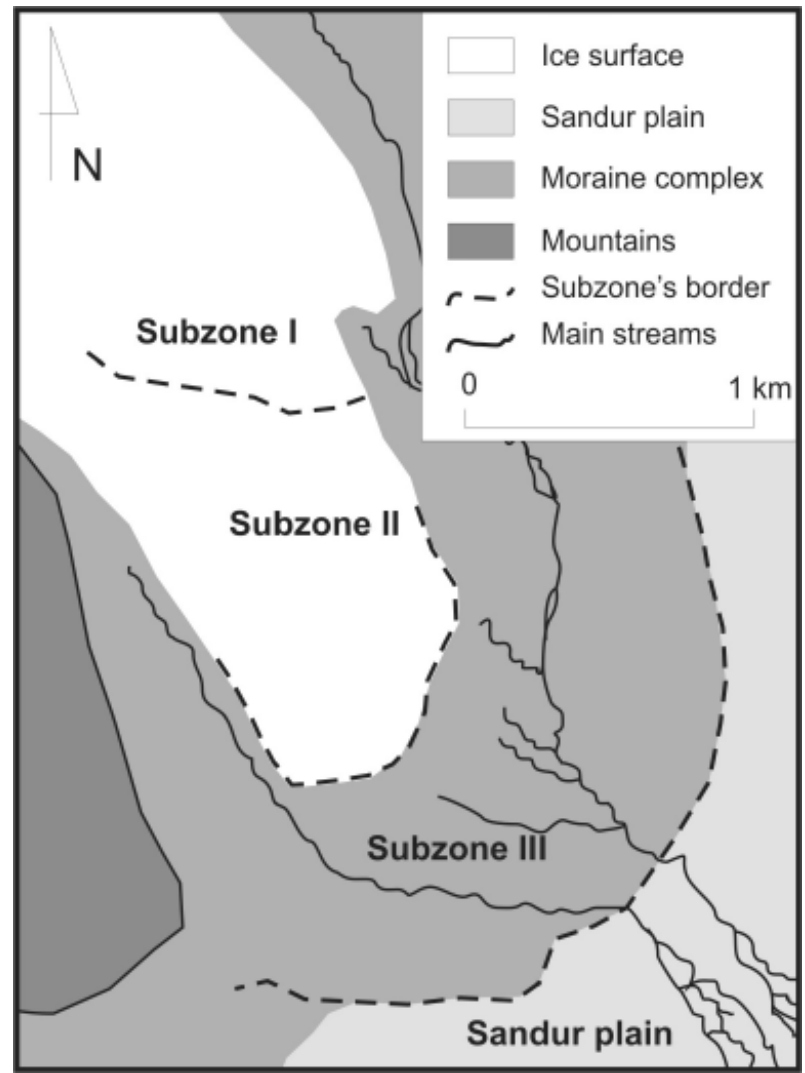

Fig. 2. Subzones of the study area in the frontal part of Hørbye glacier
- clean ice surface - Subzone I

- debris covered debris covered ice fractures - Subzone II

- moraine complex - Subzone III

The sandur plains in the distal part of the foreland of the glacier and inside the moraine complex (inner sandur) are not discussed in this study. The mapping of fractures and foreland landforms, basic sedimentological analyses were done and the differences between longitudinal and transversal forms were emphasized.

\section{Moraines development}

Two main directions of fractures were identified at the Hørbye glacier surface. (1) Longitudinal, parallel to the ice foliations, appearing on the ice surface as medial moraines and (2) the transverse fractures, expressed as thrust-moraines. Both arrangements are present also within the marginal zone. However, the morphological expression of such landforms show significant diversity along the longitudinal profile from upper part of glacier toward the marginal zone. Each of three subzones is presented below. 


\section{Subzone I - clean ice surface}

This subzone appears in the upper part of the glacier. The ice surface is inclined from northwest towards south-east. A lot of supraglacial rivers flow on the ice surface, some of them reach a huge moulin in the lower, eastern part of the glacier. In general, the ice surface is free of debris cover, except lateral parts of the glacier, adjacent to the mountains ridges, which are covered supraglacialy along ice fractures (Fig. 3A).

\section{Subzone II - debris covered ice fractures}

Melting is more intense in the frontal zone and the ice surface lowers more dynamically than the upper part of the glacier. That implies releasing of englacial and subglacial material from debris-rich plains. Debris-filled fractures form a two-directional linearity: transverse and longitudinal. The material within the longitudinal ones is poorly sorted and the clasts are mostly angular or subangular. The debris is light-coloured. The depositional effectiveness of longitudinal planes is much lower than of the transverse ones (Fig. 3C). It is expressed in the debris yield difference and consequently in distinctiveness of the landforms at the moraine complex subzone. Whereas, the thrust or shear planes (Fig. 3B) uplift finer and better rounded material, probably due to higher friction. The debris is dark-coloured. Probably, an active transport along fractures does not takes place presently, and the sediments are released in a passive way during ice melting. The debris cover is continuous and the influence of the ice structure on ridges arrangement is clearly visible (Fig. 3D). Different situation occurs in the eastern part of the glacier, where the debris cover is not so dense as in the western part and the sediments refer mostly to the thrust and shear planes as well as to the longitudinal foliation (Fig. 3E).

\section{Subzone III - moraine complex}

The fractures pattern within the ice is transferred to the marginal zone. The debris from the longitudinal foliation creates longitudinal moraines, and from the transverse fractures cre- ates thrust-moraines respectively. Overlapping of those two-directional linearities results in a checked-pattern of landforms.

The transverse hummocks are arranged in chains or appear as separate hummocks, nevertheless they form lines parallel to the ice front. Thrust-moraines are of only few meters wide and a few to tens of meters long. They are steep and sharp. In turn, the longitudinal moraines are lower and more gentle. Sometimes they even form boulder belts (Fig. 3F). Small, isolated sedimentary basins are found between transversal and longitudinal moraines (Fig. 3F). Accumulation of fine fractioned deposits, mainly laminated sand and silt takes place inside them. Depressions act as traps for sediments and periodically for water.

The primary landscape is currently remodelled by fluvioglacial and mass-movement processes. Intense fluvioglacial processes do not affect the western part of the glacier hidden in the mountain shade. The eastern side of the glacier, is drained by rather concentrated drainage system, in turn. The main river runs out in the foreland from the ice tunnel and gathers water of smaller streams.

\section{Discussion}

Sediments are accumulated an the ice surface and delivered to the marginal zone in two ways. Firstly, supraglacialy (e.g. Eyles, 1979) or secondly, along ice fractures (e.g. Boulton, 1967). Lyså \& Lønne (2001) inferred on the basis of theirs researches on the Rieperbreen glacier, that nowadays the supraglacial source is of high importance in debris delivery to the glacier margin. But in the case of the Hørbye glacier, the transport yield seems to had been most effective via sub- and englacial positions. The ice surface of the Hørbye glacier is generally clean, except debris melted out from ice fractures and the lateral parts of glacier (Fig. 3D), so the subglacial transport had to play a main role. Even if the debris delivery is effective, Graham \& Midgley (2000) suggested that, the formation of thrust-moraine complex requires both sediments incorporation into the thrust planes and appropriate conditions for moraine preservation. Incorporation of subglacial material, in case of Hørbye glacier, along thrust planes was high enough to create distinct forms 


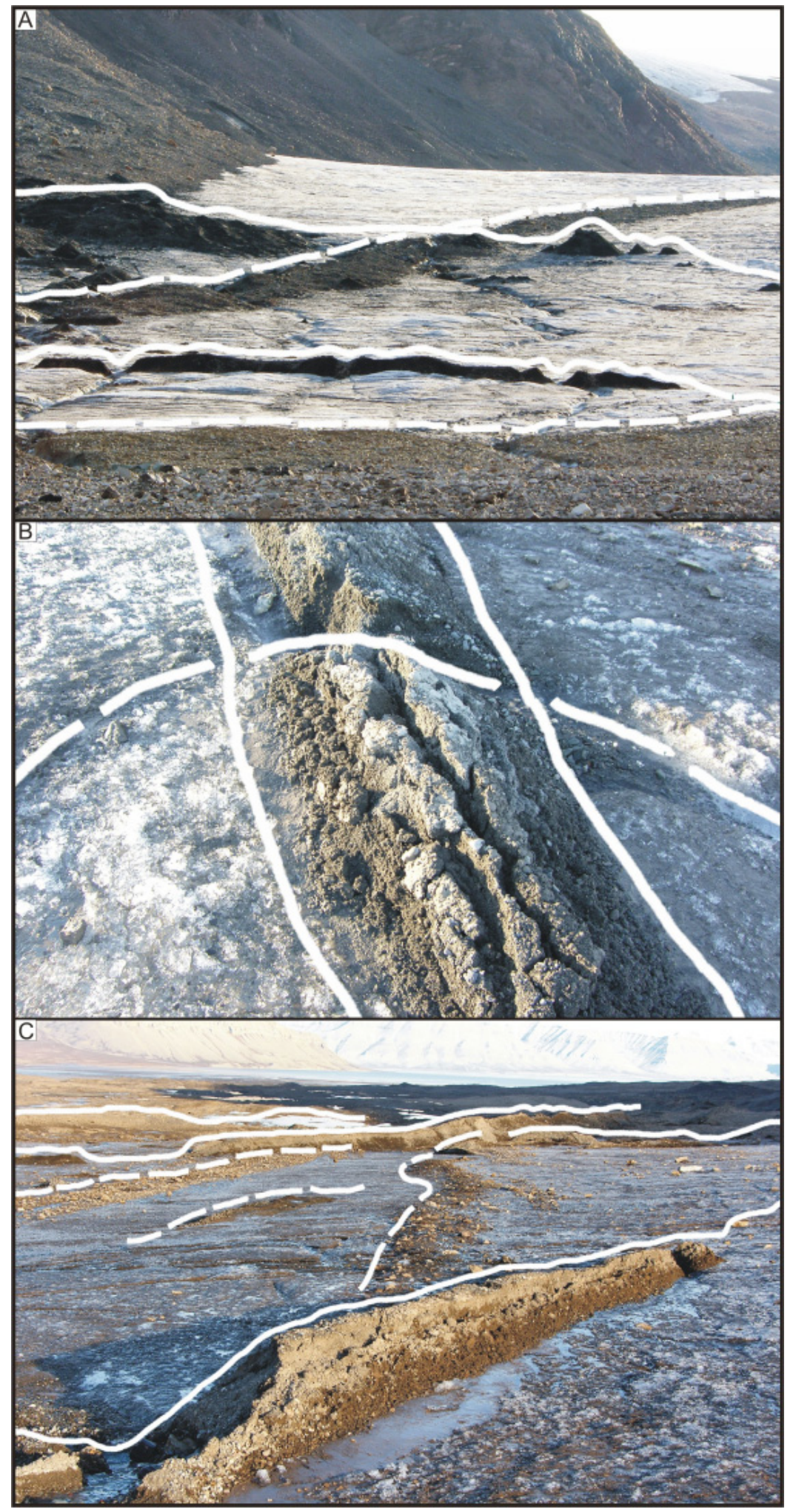

Fig. 3. Photos from the study area (longitudinal forms - dashed line, transversal forms - solid line). A - Subzone I, upperside part of the glacier, clean ice surface with visible longitudinal and transverse moraine ridges; B - Subzone II, shear plane; C - Subzone II, debris material melted out from transverse fractures and longitudinal foliations 


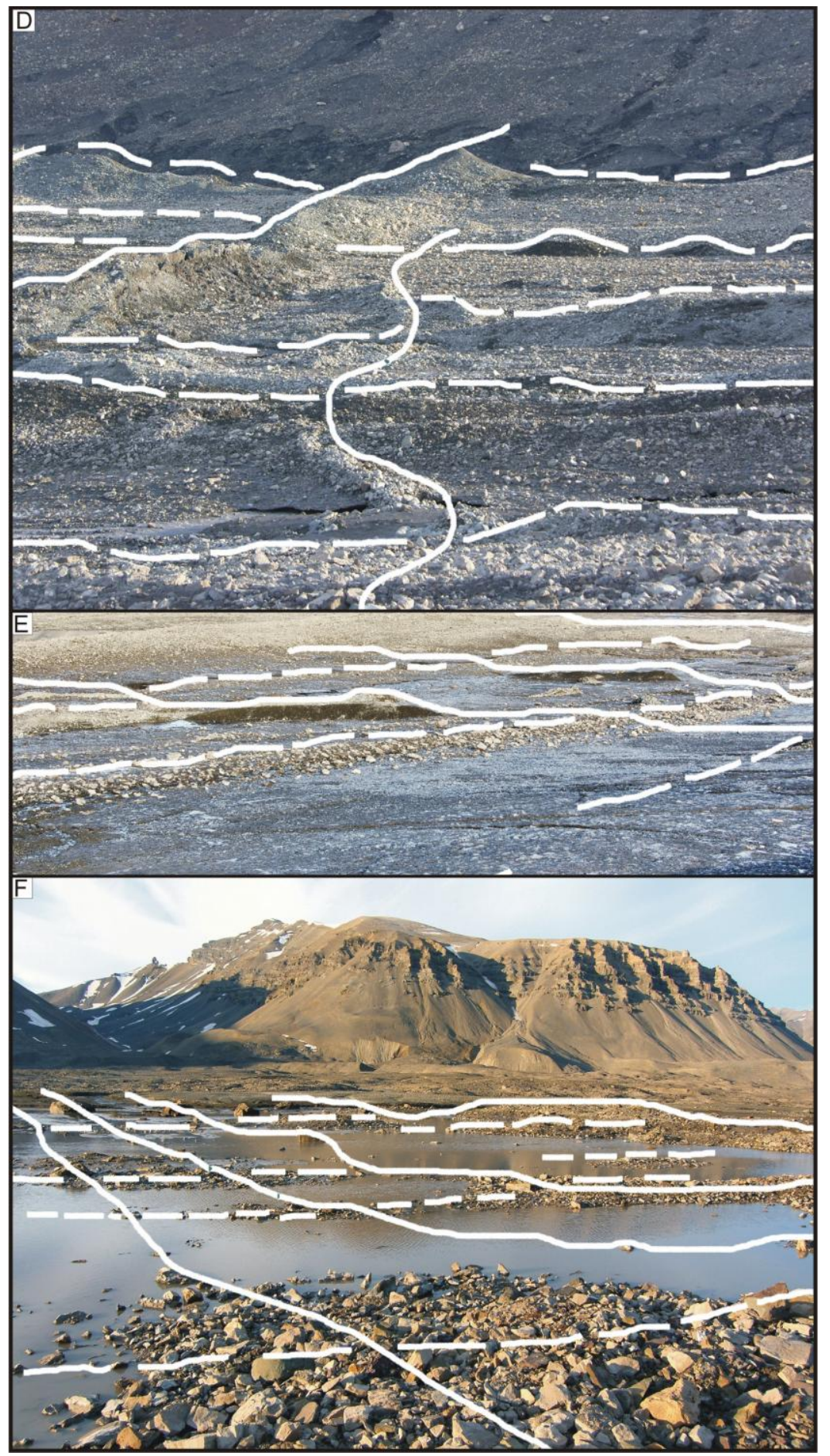

Fig. 3. cont.; D - Subzone II, lower-western part of the glacier, the debris covered ice surface with marked higher elevated transversal forms and lower longitudinal ones; E - Subzone II, lower-eastern part of the glacier, debris free ice surface with clearly visible checked-pattern of controlled moraines ridges; F - Subzone III, morphology of moraine complex in front of the Hørbye glacier. The checked-pattern of linear forms is inherited after longitudinal and transversal fractures. Photographs: L. Kasprzak 
in the moraine subzone. The results of Hambrey et al. (1999) investigations confirmed basal origin of some debris found supraglacialy - they interpreted those sediments as englacial and subglacial material. The authors had not a possibility to confer the sediments from glacier bed with those on the ice surface, but in the light of Hambrey et al. (1999) researches, the statement of basal origin of our supraglacial material can be accept.

The size of controlled moraines, as Evans (2009) pointed out, depends on the content of englacial debris and consequently of the basal thermal regime which in turn influences on the delivery of debris along thrust and shear plains. The effectiveness of thrust-moraines formation on ice surface changes due to two factors. On the one hand, the effectiveness depends on intensity of melting processes. The more intense melting is, the more material is released from debris-rich shear and thrust plains. On the other hand, the debris incorporation along the fractures and plains and as well as debris delivery is related to a thermal regime. As already mentioned before, the Hørbye glacier is polythermal (Gibas et al., 2005) and in that case, sediments incorporation was probably the most effective at the boundary between cold-based and warm-based ice (Sollid \& Sørbel, 1988).

Likewise, it should be remembered that the process of englacial thrusting is not directly responsible for final moraines creation (Lucas, 2007). The final shape of those moraines is created by melting out of buried ice and redepositional processes. Lucas (2007) also affirms that de-icing processes in modern glaciated areas are so dynamically, that the debris released from englacial thrust can not preserv in situ. Graham et al. (2007) believed at the time, that the structure of ice is most likely to be overdrawn and preserved when the volume of sediments is large. It was also concluded by Bennett et al. (1999) that in the case of steep thrusts more material is left at the base of thrusts and less material is uplifted. But contemporary, the discussion about steepness of thrusts is impossible, because only the lower part of the glacier is visible. During the last 40 years the ice surface of the Hørbye glacier lowered about $40 \mathrm{~m}$ (Rachlewicz et al. 2007). Considering the valley position of the Hørbye glacier, with its dynamically remodeled surface relief and the lack of preservation of pre-LIA forms, the preservation potential of controlled moraines is rather low on a longer time scale.

Šinkūnas et al. (2009) argue that localization and condition of sediments in glacial environment influence the diversity of landforms. However, the present authors claim that landforms localization and sediments distribution is controlled first by the ice structure and afterwards by secondary processes, like fluvioglacial or redepositional ones.

With reference to the mentioned discussion about controlled topography, a simplified model of controlled moraine developement is proposed (Fig. 4).

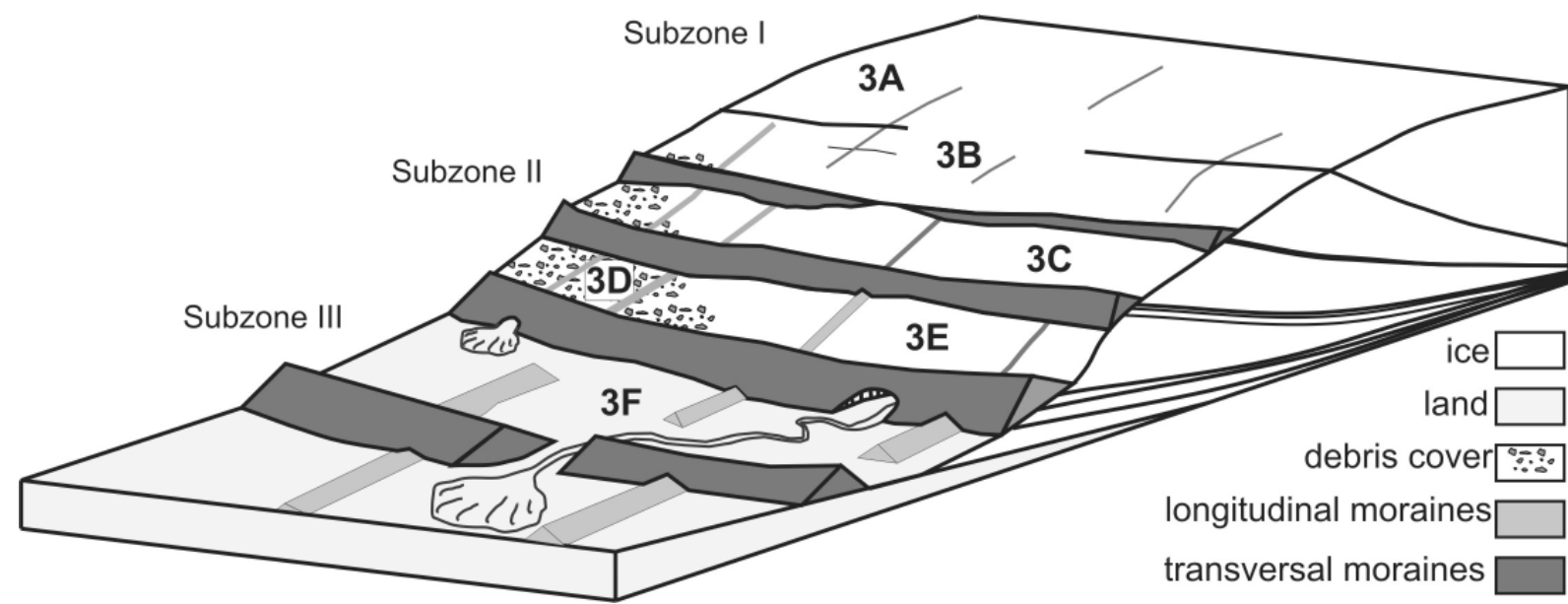

Fig. 4. Schematic model of controlled topography with a reference to the glacier ice structures. 3A, B, C, D, E, F - symbols of photos from Fig. 3. Further explanations in the text 
During the LIA the ice front was steeper than presently. The fractures and foliation were developed in response to the ice flow, extension and compression within the ice mass. On the glacier surface fractures and crevasses were common. Englacial thrusting was the most intense at the boundary between warm-based and cold-based ice (Sollid \& Sørbel, 1988). Supraglacial material yield was higher than now, due to more intense mountain erosion. However, the intensity of subglacial processes and debris uplifting was more important than supraglacial yield. Due to climate warming after the maximum of the LIA, the Hørbye glacier has been in retreat. This recession causes lowering of the ice surface. The debris material within the ice fractures was melted out and in a consequence the englacial and subglacial sediments formed linear moraine ridges at the ice surface. Debris forming longitudinal belts is more dispersed, rather accumulated within thick, wide boulder belts (Fig. 3C - dashed lines). On the other hand thrusts create steeper and narrower, transverse chains (e.g. Fig. 3D). Chains of steep thrust-moraines and boulder belts remain in the marginal zone after the retreat of the ice front. A moraine topography is arranged in regular pattern (Figs. 3E, F). The central part of each cell of the pattern is occupied by a depression filled with finer sediments and periodically by water (Fig. 3F).

After the recession of Hørbye glacier the controlled topography inherited from the ice structure will be visible, i.e. marginal landforms like thrust- and longitudinal moraines (at least for some period of time). Massmovement processes will take greatest role in topography remodelling because fluvioglacial processes are even now limited to few narrow parts of the foreland. Longitudinal moraines will probably leave boulder belts, that can be observed also nowadays. Thrust moraines will persist as hummocky chains built of finer and darker deposits. Central parts of each cell of the patterned terrain will exist as a plot of fine sediments. However those forms will not be preserved for a larges period.

To sum up, the location and formation of medial, longitudinal and thrust moraines, is controlled by longitudinal sediment belts, shear and thrust fractures arrangement within the ice and intense debris delivery, as well as melting processes. Therefore the term "controlled topography" proposed firstly by Boulton (1967, 1972) and modified into "controlled moraines" by Benn \& Evans (1998) is appropriate to define the forms described in this study. The role of ice-marginal deposition is also important for moraine formation, but the aim of this study was to verify the significance of ice structure in landscape shaping, therefore ice-marginal model was omitted.

\section{Conclusion}

On the basis of our field observations and the literature review it is suggested that the foreland topography of the Hørbye glacier is controlled by ice structure. The moraine complex at the Hørbye glacier is formed mainly by melting out debris from fractures and longitudinal belts of deposits. The majority of sediments was incorporated into the glacier probably during the LIA, when the glacier was more active. The high intensity of subglacial incorporation processes was favored by a polythermal regime. The ice structure is likely to influence the foreland topography and that is why the landforms in the moraine complex subzone of the Hørbye glacier own the patterned arrengement. The depressions between elevated longitudinal and thrust moraines constitute a system of separate sedimentary traps. In the central part of each depression fine sediments are accumulated and water is retentioned periodically. The sediments within transversal plains are finer and better rounded than in longitudinal ones, where the clasts are poorly sorted and worse rounded. That is probably a result of higher friction in transverse planes, discordant to the ice flow direction.

Depositional potential of structural fractures is diversified. Thrust and shear planes are of greater significance in landforms creating. But also the longitudinal fractures play an important role. A system of boulder belts, (instead of medial and thrust moraines) and plots of finer, laminated material (instead of depressions) may be preserved in the landscape, but probably for a short time scale. However, observations within the modern glacial environment can be helpful in understanding sedimentary basins creation. 


\section{Acknowledgements}

The authors are grateful to E. Lipka for language proofreading of the manuscript.

\section{References}

Benn D.I. \& Evans D.J.A., 1998. Glaciers and Glaciations. Arnold, London: $195 \mathrm{pp}$.

Bennett M.R, Hambrey M.J., Huddart D. \& Glasser N.F., 1998. Glacial thrusting and moraine-mound formation in Svalbard and Britan: the example of Coire a' Cheudchnoic (Valley of hundred hills), Torridon, Scotland. Quaternary Proceedings 6: 17-34. DOI: 10.1016/S0169555X(00)00017-9

Bennett M.R., Hambrey M.J., Huddard D., Glasser N.F. \& CRAWFORD K., 1999. The landform and sediment assemblage produced by a tidewater glacier surge in Kongsfiorden, Svalbard. Quaternary Science Reviews 18 (10-11): 1213-1246.

BOULTON G.S., 1967. The development of a complex supraglacial moraine at the margin of Sørbreen, Ny Friesland, Vestspitsbergen glaciers. Journal of Glaciology 6: 717-736.

Boulton G.S., 1972. Modern Arctic glaciers as depositional models for former ice sheets. Journal of the Geological Society of London 128: 361-393. DOI: 10.1144/ gsigs.128.4.0361

Dowdeswell J.A., Hagen J.O., BJÖRnsson H., GlazovsKY A.F., Harrison W.D., Holmlund P., Jania J., Koerner R.M., Lefauconnier B., Ommanney C.S.L. \& Thomas R.H., 1997. The mass balance of circum-Arctic glaciers and recent climate change. Quaternary Research 48, 1-14.

Evans D.J.A., 2009. Controled moraines:origins, characteristics and paleoglaciological implications. Quaternary Science Reviews 28: 183-208.

EYLES N., 1979. Facies of supraglacial sedimentation on Icelandic and alpine temperate glaciers. Candian Journal of Earth Sciences 16: 1341-1361.

Gibas J., Rachlewicz G. \& Szczuciński W., 2005. Application of DC resistivity sounding and geomorphological surveys in studiem of modern Arctic glacier marginal zones, Petuniabukta, Spitsbergen. Polish Polar Research 26: 239-258.

Glasser N.F., Hambrey M.J., Crawford K., Bennett M.R. \& HudDART D., 1998. The structural glaciology of Kongsvegen, Svalbard, and its role in landform genesis. Journal of Glaciology 44: 136-148.

Graham D.J., Bennett M.R., Glasser N.F., Hambrey M.J., Huddart D. \& Midgley N.G., 2007. 'A test of the englacial thrusting hypothesis of "hummocky" moraine formation: case studies from the northwest Highlands, Scotland': Comments. Boreas 36: 103-107.

Graham D.J. \& Midgley N.G., 2000. Moraine-moud formation by englacial thrusting: the Younger dryas moraines of Cwm Idwal, North Wales. In: A.J. Maltman, B. Hubbard \& M.J. Hambrey (eds.), Deformation of glacial materials. The Geological Society, London: 321-336.
Hambrey M.J., Bennett M.R., Dowdeswell J.A., Glasser N.F. \& Huddart D., 1999. Debris entrainment and transfer in polythermal valley glaciers. Journal of Glaciology 45: 69-86.

Hambrey M.J., Huddart D., Bennett M.R. \& Glasser N.F., 1997. Genesis of hummocky moraines by thrusting of glacier ice: evidence from Svalbard and Britain. Journal of the Geological Society of London 154: 623-632.

KARCZEWSKI A., 1989. The development of the marginal zone of the Hørbyebreen, Petuniabukta, central Spitsbergen. Polish Polar Research 10: 371-377.

KarCZEWSKI A. \& RyGielsKi W., 1989. The profile of glacial deposits in the Hörbyedalen and an attempt at their chronostratigraphy central Spitsbergen. Polish Polar Research 10: 401-409.

LYSÅ I. \& LøNNE A., 2001. Moraine development at a small High-Arctic valley glacier: Rieperbreen, Svalbard. Journal of Quaternary Science 16: 519-529. DOI: 10.1002/ jqs.613

LuCAS S., 2005. A test of the englacial thrusting hypothesis of 'hummocky' moraine formation: case studies from the north west Highlands, Scotland. Boreas 34: 287-307.

LUCAS S., 2007. 'A test of the englacial thrusting hypothesis of "hummocky" moraine formation: case studies from the northwest Highlands, Scotland': Reply to comments. Boreas 36: 108-113.

Lukas S., Nicholson L.I., Ross F.H. \& Humlum O., 2005. Formation, meltout processes and landscape alteration of High-Arctic ice-Cored moraines: examples from Nordenskiold Land, Central Spitsbergen. Polar Geography 29 (3), 157-187. DOI: 10.1080/789610198

Murray T., Gooch D.L. \& Stuart G.W., 1997. Structures within the surge front at Bakaninbreen,Svalbard, using ground-penetrating radar. Annals of Glaciology 24: 122$-129$.

Rachlewicz G., Szczuciński W. \& Ewertowski M., 2007. Post - "Little Ice Age" retreat rate of glaciers around Billefjorden in central Spitsbergen, Svalbard. Polish Polar Research 28: 159-186.

ŠinKŪNAs P., ČESNUleVIČIUS A., Karmaza B. \& BALtrūnas V., 2009. Glacigenic landforms features in marginal zone of Russell and Leverett glaciers, West Greenland. Geologija 51, 23-32.

SOLLID J.L. \& SørBel L., 1988. Influence of temperature conditions in formation of end moraines in Fennoscandia and Svalbard. Boreas 17: 553-558.

Svendsen J.I. \& MANGERund J., 1997. Holocene glacial and climatic variations on Spitsbergen, Svalbard. The Holocene 7: 45-57.

Woodward J., Murray T. \& McCaig A., 2002. Formation and reorientation of structure in the surge-type glacier Kongsve gen, Svalbard. Journal of Quaternary Science 17(3), 201-209.

Zagórski P., SiweK K., Gluza A. \& BartoszewsKi S., 2008. Changes in the extent and geometry of the Scott Glacier, Spitsbergen. Polish Polar Research 29(2), 163-185.

ZiAJA W., 2001. Glacial recession in Sørkappland and central Nordenskiöldland, Spitsbergen, Svalbard, during the $20^{\text {th }}$ century. Arctic Antarctic and Alpine Research 33, $36-41$. 